\title{
Assessment of Estrogen receptor Expression in Carcinoma Breast cases presenting to a tertiary care hospital in Andhra Pradesh
}

\author{
Challapalli Srikanth Reddy, Chilakala Archana, Bathalapalli SrihariRao, Shankar Reddy Dudala, Jambapuram Bharath \\ prakash Reddy , Thalamati Sujana
}

S.V.Medical College \& S.V.R.R.G.G.Hospital, Tirupati, Andhra Pradesh, India.

\section{Abstract}

Breast carcinoma is the most common malignant tumor and the leading cause of death, in women, worldwide. It accounts for $15 \%$ of all cancer deaths. Various protocols are in use for the assessment of prognosis, and also to assist in planningfurther management of these cases. Of various parameters, expression of Estrogen receptors (ER) is significant. The literature includes several studies showing association between the presence of estrogen receptors apart from other indicators of good prognosis like small tumor size, low histological grade, low nuclear grade and low mitotic activity. It is also a powerful predictive factor for the likelihood of benefit from adjuvant hormonal therapy including aromatase inhibitors (Anastrozole, letrozole) and Tamoxifen, an oral selective estrogen receptor modulator. All cases of Carcinoma breast presenting to S.V.R.R.G.G. Hospital, are evaluated for Estrogen Receptor status using immunochemistry, indirectly assessing the prognosis of individuals presenting to the Hospital and in turn the prognosis of the disease in the region.

Key Words: Breast carcinoma, Estrogen receptors, predictive factor, Prognosis.

\section{INTRODUCTION}

Breast carcinoma is the most common malignant tumor and the leading cause of death, in women, worldwide1. It accounts for $15 \%$ of all cancer deaths 2 . Various protocols are in use for the assessment of prognosis, and also to assist in planning further management of these cases. Of various parameters, expression of Estrogen receptor (ER) is significant. Estrogen receptors 6 are a group of proteins found inside cells. They are receptors that are activated by the hormone estrogen estradiol). Once activated by estrogen, the estrogen receptor is able to bind to DNA and regulate the activity of many different genes

The ERs are regarded to be cytoplasmic receptors in their unliganded state, but research has shown that a fraction of the ERs resides in the nucleus. Since estrogen is a steroidal hormone, it can pass through the phospholipid membranes of the cell, and receptors therefore do not need to be membrane-bound in order to bind with estrogen. In the absence of hormone, estrogen receptors are largely located in the cytosol.

Hormone binding to the receptor triggers a number of events starting with migration of the receptor from the cytosol into the nucleus, dimerization of the receptor, and subsequent binding of the receptor dimer to specific sequences of DNA known as hormone response elements.

The DNA/receptor complex then recruits other proteins that are responsible for the transcription of downstream DNA into mRNA and finally protein that results in a change in cell function. Estrogen and the ERs have also been implicated in ovarian cancer, colon cancer, prostate cancer, and endometrial cancer[1-5].

In India estrogen receptor expression is found to be low. In a study conducted by Tanuja Shet et al [6] hormone receptor

\footnotetext{
Address for correspondence*

Dr. C. Srikanth Reddy,

Asst. Professor of Surgery,

S.V.Medical College \& S.V.R.R.G.G.Hospital,

Tirupati, Andhra Pradesh,

India.
}

expression in India, was found to be low. Their study was undertaken to know percentage of female breast cancers expressing estrogen receptor and progesterone receptor in the locality in different age groups.

\section{MATERIALS AND METHODS}

This prospective study of carcinoma breast was carried out in patientsadmitted to SVRRGG Hospital, Tirupati during the period from January 2013 to August 2014.Hundred cases of breast carcinoma were taken into study.

The clinical study done by interviewing, detailed examination and subjecting to relevant investigations and surgeries, depending upon the stage of the disease. Excised specimen is sent for Histopathological examination in $10 \%$ formaline.

Reports of light microscopy (Hematoxylin and Eosin) and immunohistochemistry on tumor histology including MBR(Modified Bloom Richardson) grading and Estrogen receptor status was analysed.

\section{METHOD OF REPORTING BY IHC}

Cut- off positivity: "Any nuclear immunostaining for ER should be considered as a positive result according to the National Institute of Health consensus, 2000.

A commonly employed threshold for positive results for ER IHC assays in terms of the potential benefit from adjuvant endocrine therapy is $1 \%$ positive tumour cells with a $1+$ or greater signal.

ER status is evaluted by immunohistochemistry technique with monoclonal antibodies (DAKO). ER positivity is assessed using Allred Score system.

The Allred score combines the percentage of positive cells and the intensity of the reaction product in most of the specimen. The 2 scores are added together for a final score with 8 possible values. 
Allred Score

\begin{tabular}{|l|l|}
\hline $\begin{array}{l}\text { Proportion } \\
\text { Score }\end{array}$ & $\begin{array}{l}\text { \% of Positive } \\
\text { Cells }\end{array}$ \\
\hline 0 & 0 \\
\hline 1 & $<1$ \\
\hline 2 & $1-10$ \\
\hline 3 & $11-33$ \\
\hline 4 & $34-66$ \\
\hline 5 & $67-100$ \\
\hline $\begin{array}{l}\text { Intensity } \\
\text { Score }\end{array}$ & $\begin{array}{l}\text { Intensity of } \\
\text { Positivity }\end{array}$ \\
\hline 0 & None \\
\hline 1 & Weak \\
\hline 2 & Intermediate \\
\hline 3 & Strong \\
\hline
\end{tabular}

The proportion score and intensity score are added together for a total score.Total score: PS+ IS Interpretation: Score of 0-2 as Negative and 3-8 as Positive.

\section{RESULTS}

Table 1: Distribution Of Er Status

\begin{tabular}{|c|c|l|}
\hline ER STATUS & FREQUENCY & PERCENTAGE \\
\hline Negative & $\mathbf{6 5}$ & $\mathbf{6 5}$ \\
\hline Positive & $\mathbf{3 5}$ & $\mathbf{3 5}$ \\
\hline Total & $\mathbf{1 0 0}$ & $\mathbf{1 0 0}$ \\
\hline
\end{tabular}

Estrogen receptor positivity was seen in $35 \%$ of cases where as receptor negativity was seen in $65 \%$ of cases.

Table 2: distribution of estrogen receptors in different Age groups

\begin{tabular}{|l|l|l|l|}
\hline $\begin{array}{l}\text { AGE } \\
\text { RANGE }\end{array}$ & $\begin{array}{l}\text { NUMBER OF } \\
\text { INDIVIDUALS }\end{array}$ & $\begin{array}{l}\text { ER STATUS } \\
\text { +VE }\end{array}$ & $\begin{array}{l}\text { ER STATUS } \\
\text {-VE }\end{array}$ \\
\hline $\mathbf{2 1 - 3 0}$ & $\mathbf{3}$ & $\mathbf{0}$ & $\mathbf{3}$ \\
\hline $\mathbf{3 1 - 4 0}$ & 22 & 7 & $\mathbf{1 5}$ \\
\hline $41-50$ & $\mathbf{3 2}$ & 7 & $\mathbf{2 5}$ \\
\hline $\mathbf{5 1 - 6 0}$ & $\mathbf{1 8}$ & $\mathbf{5}$ & $\mathbf{1 3}$ \\
\hline $\mathbf{6 1 - 7 0}$ & $\mathbf{2 2}$ & $\mathbf{1 5}$ & 7 \\
\hline $71-80$ & $\mathbf{3}$ & $\mathbf{3}$ & $\mathbf{0}$ \\
\hline
\end{tabular}

Majority of ER positivity seen in elderly age group i.e, between $61-70$ yrs. Patients between 31-40 and 41-50 form second most common ER positive age group. Majority of ER negativity is seen between 41-50 yrs. Second most common ER negative age group is between 31 and $40 \mathrm{yrs}$. The statistic analysis is done using fischer exact test according to which the $\mathrm{p}$ value is 0.3068 which is not significant.

Table 3: Distribution Of Parity Status

\begin{tabular}{|c|c|c|c|}
\hline PARITY & FREQUENCY & ER +ve & ER -ve \\
\hline 0 & $5(5 \%)$ & $\mathbf{0}$ & 5 \\
\hline $1-3$ & $75(75 \%)$ & 30 & 45 \\
\hline $4+$ & $20(20 \%)$ & 5 & 15 \\
\hline Total & $100(100 \%)$ & 35 & 65 \\
\hline
\end{tabular}

$5 \%$ patients are nulliparous. $20 \%$ have more than 4 children. $75 \%$ have less than 4 children. Nulliparous women had ER negative tumors. Even in multiparous women, ER negativity predominates.

Table 4: Distribution Of Er Status According To Tumor

\begin{tabular}{|l|l|l|l|}
\hline TUMOR & ER +VE & ER -VE & TOTAL \\
\hline T1 & 3 & 0 & 3 \\
\hline T2 & 15 & 17 & 32 \\
\hline T3 & 12 & 20 & 32 \\
\hline T4 & 5 & 22 & 27 \\
\hline PAGETS & 0 & 3 & 3 \\
\hline TX & 0 & 3 & 3 \\
\hline TOTAL & 35 & 65 & 100 \\
\hline
\end{tabular}

$32 \%$ patients presented with $\mathrm{T} 2$ and $\mathrm{T} 3$ tumors each. $27 \%$ presented with T4. 3\% cases presented with T1, Pagets and Tx each. $81 \%$ of T 4 tumors are ER negative. $61 \%$ of T3 tumors are ER negative. $53 \%$ of T2 tumors are ER negative. chi square is 3.65. $\mathrm{p}$ value $=0.17$ hence not significant. Whereas in T1 tumors, ER status was positive in all the cases, and in Pagets and TX tumors, ER status was negative in all the cases.

Table 5: Distribution Of Er Status According To Nodal Status

\begin{tabular}{|l|l|l|l|}
\hline NODAL STATUS & ER +VE & ER -VE & TOTAL \\
\hline N0 & 20 & 30 & 50 \\
\hline N1 & 9 & 32 & 41 \\
\hline N2 & 3 & 3 & 6 \\
\hline N3 & 3 & 0 & 3 \\
\hline TOTAL & 35 & 65 & 100 \\
\hline
\end{tabular}

Among node negative patients $60 \%$ had ER negative tumors. Among N1 patients $78 \%$ had ER negative tumors. $50 \%$ of N2 cases had ER-ve tumors. All patients who had N3 were ER positive. $p$ value is 0.2 hence insignificant.

Table 6: Distribution Of Er Status According To Metastasis

\begin{tabular}{|l|l|l|l|}
\hline METASTASIS & ER +VE & ER -VE & TOTAL \\
\hline M0 & $\mathbf{3 5}$ & $\mathbf{6 2}$ & $\mathbf{9 7}$ \\
\hline M1 & $\mathbf{0}$ & $\mathbf{3}$ & $\mathbf{3}$ \\
\hline TOTAL & $\mathbf{3 5}$ & $\mathbf{6 5}$ & $\mathbf{1 0 0}$ \\
\hline
\end{tabular}

$65 \%$ of patients without metastasis had ER-ve status. $35 \%$ patients without metastasis had ER positive status. ER -ve status was seen in all the patients having metastasis. $\mathrm{P}$ value is 0.56 hence insignificant.

Table 7: Distribution Of Er Status According To Modified Bloom Richardson Grading

\begin{tabular}{|l|l|l|l|}
\hline MBR GRADING & ER +VE & ER -VE & TOTAL \\
\hline I & $\mathbf{2 2}$ & $\mathbf{1 5}$ & $\mathbf{3 7}$ \\
\hline II & $\mathbf{1 0}$ & $\mathbf{4 0}$ & $\mathbf{5 0}$ \\
\hline III & $\mathbf{3}$ & $\mathbf{1 0}$ & $\mathbf{1 3}$ \\
\hline TOTAL & $\mathbf{3 5}$ & $\mathbf{6 5}$ & $\mathbf{1 0 0}$ \\
\hline
\end{tabular}

Majority (80\%) of grade III tumors are ER negative. Majority of ER positive tumors are grade I. $60 \%$ of grade I tumors are ER positive. $20 \%$ of grade II tumors are ER positive. Probability is 0.037 which is significant. Majority $(80 \%)$ of grade II tumors are ER negative. 


\section{CONCLUSION}

In the recent years there has been outstanding advances in breast cancer diagnosis and management leading to earlier detection of disease and the development of more effective treatment. This has resulted in improved quality of life with significant decline in breast cancer deaths for those women living with the disease. Prognosis and management of breast cancer are influenced by classic variables such as histologic type and grade, tumor size, lymph node status, status of Estrogen receptors. In this study an attempt was made to understand the correlation of ER status with histopathological grading and clinicopathological parameters. In the present study relatively lower incidence of Estrogen receptor expression was noted, but ER status correlates well with histopathological grading and other clinico-pathological parameters. Higher grade is associated with ER negativity. Hence, the prognosis of Breast carcinoma in this region is likely to be poor, necessitating early diagnosis and intervention, inorder to improve the survival rates.

\section{REFERENCES}

1. Parkin DM B, Ferlay J, et.al. . Estimating world cancer burden Globocan. Int J Cancer 2001;94:153-6.
2. Woodsen. RVD. The Problem- Prevalence of breast cancer. Philippines 2010.

3. Lester SC KV, Abbas AK, Fausto N, Aster JC, editors. The Breast. Robbins and Cotran Pathologic Basis of Disease, 8th ed. Kumar V, Abbas AK, Fausto N , Aster JC, editors.Philadelphia : Saunders, 2010, 1065-97. Robbins and Cotran Pathologic Basis of Disease Philadelphia : Saunders, 2010;8th edition:1065-87.

4. Fisher B JJ, Bryant J, et.al. Treatment of lymph-nodenegative, estrogenreceptor- positive breast cancer: longterm findings from National Surgical Adjuvant Breast and Bowel Project randomised clinical trials. Lancet 2004;364 (9437):858-68.

5. Group EBCTsC. Tamoxifen for early breast cancer; an overview of the randomised trials. Early Breast Cancer Trialist's Collaborative Group. Lancet 1993;351 (9114):1451-67.

6. Tanuja Shet AA, Mandar nadkarni et.al. . 'Harmone receptors over the last 8 years in a cancer referral centre in India". Indian J of Patho and Micro dept of Path Sur Oncology 2009 April-June;52:171-4. 